\section{Euroson 2020 til Bergen}

I juni 2020 arrangeres den årlige Eurosonkongressen i Grieghallen i Bergen. Euroson er den offisielle kongressen til European Federation of Societies for Ultrasound in Medicine and Biology (EFSUMB) som NFUD er en del av. NFUD er medarrangør og Euroson erstatter NFUDs symposium for 2020. Velkommen til Bergen!

\section{Sett av datoene}

Eurosonkongressen arrangeres over tre dager fra 11. til 13. juni 2020. Her samles studenter, klinikere, ingeniører og industri til en innholdsrik kongress med fokus på læring og utveksling av erfaring og kunnskap, og presentasjon av ny og fremtidig teknologi. NFUD er medarrangør sammen med Nasjonal kompetansetjeneste for gastroenterologisk ultralyd (NSGU) ved Haukeland universitetssykehus, i samarbeid med våre danske og svenske søsterorganisasjoner og Sono Scandinavia. Det vil bli både fellessesjoner, frie foredrag med forskning og kasuistikker, parallellsesjoner for de ulike fagdisiplinene, demonstrasjoner og praktisk trening.

\section{Hands-on trening}

Det vil bli lagt til rette for praktisk trening $\mathrm{i}$ de ulike disiplinene, hvor deltakerne vil veiledes av eksperter. I tillegg vil SonoScandinavia, for første gang på Euroson, arrangere et kurs i pasientnær/point-of-care ultralyd (POCUS). I POCUS er den typiske brukssituasjon av ultralyd en målrettet undersøkelse utført av klinikeren ved pasientsengen i akuttmottaket eller under visitten. Det blir også et eget kurs for studenter om bruk av ultralyd i akuttmedisin. Nytt av året er også et etterutdanningskurs i leverelastografi med hands-on trening.

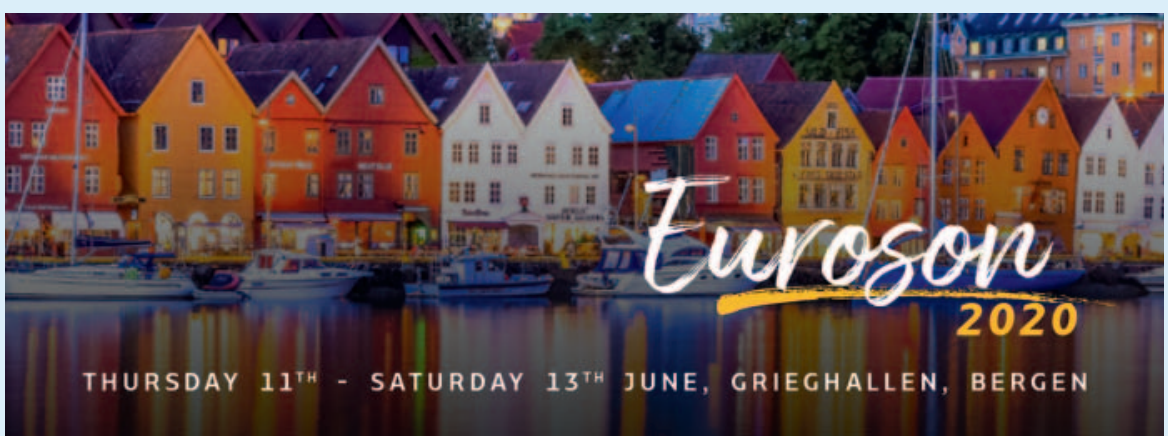

\section{Inviterte foredragsholdere}

Programmet vil by på flere parallellsesjoner som gir en enestående mulighet til å få oppdatert informasjon om det siste nye innen gyn/obs, muskel/skjelett og abdomen. Et videre høydepunkt vil være presentasjon av aksepterte abstrakt. Flere eminente foredragsholdere er invitert; av foredragsholdere til obstetrikksesjonene kan vi nevne Dr. Tullio Ghi (Italia), Professor Lil Valentin (Sverige) og Dr. Alexandros Sotiriadis (Hellas). Vi kan også vente oss spennende foredrag innen muskel/ skjelett-avbildning fra Dr. Stefan Moosmayer (Norge), Dr. Tore Prestgaard (Norge), Dr. Marnix van Holsbeeck (USA), Lene Terslev (Danmark) og Ingrid Möller (Spania). Det blir et svært sterkt program innen ultralyd elastografi, hvor blant annet professor Giovanna Ferraioli fra Universitetet i Pavia (Italia) og professor Jeffrey Bamber fra Universitet i London (England) vil være blant foredragsholderne. Også Dr. Christoph Dietrich (Tyskland) vil holde foredrag innen generell ultralyd. Professor Christian Pállson Nolsøe fra Universitetet i København og professor Peter Burns fra Universitetet i Toronto (Canada) er inviterte foredragsholdere og vil ha spennende innlegg innen intervensjon og kontrastavbildning. Professor Alison Noble fra Oxford Universitetet (England) vil presentere spennende forskning med kunstig intelligens og maskinlæring innen obstetrikk.

Fullstendig program blir publisert på euroson2020.org. Gå dit for innsending av abstrakt, registrering og mer informasjon.

\section{Følgende frister er verdt å merke seg:}

- 2. januar 2020: Registrering til kongressen åpner

- 15. februar: Frist for innsending av abstrakt

- 1. mars: Frist for early bird-registrering

- 1. april: Tilbakemelding om hvorvidt abstraktet er akseptert til poster eller muntlig presentasjon

\section{Nye hjemmesider for NFUD}

Vi kan ellers melde om at nfud.no har fått nytt design! Styret i NFUD ønsker å gjøre hjemmesidene mer relevante for nåværende og fremtidige medlemmer, der medlemsfordelene kommer tydelig frem. Linker viser vei til faglig material som medlemmer har tilgang til, og i tillegg kan man på hjemmesidene finne interessante nyheter, oversikt over relevante kurs og spennende forskning og kasuistikker. 